\title{
The impacts of customer satisfaction on loyalty of the youth (18-25 years old) towards e-commerce trading floors in Ho Chi Minh City
}

\author{
Nguyen Thi Quynh Nga*, Do Hong Van
}

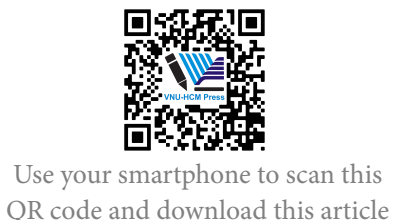

QR code and download this article

Foreign Trade University, Vietnam

\section{Correspondence}

Nguyen Thi Quynh Nga, Foreign Trade

University, Vietnam

Email:

nguyenthiquynhnga.cs2@ftu.edu.vn

History

- Received: 9/7/2020

- Accepted: 16/10/2020

- Published: 16/11/2020

DOI : 10.32508/stdjelm.v4i4.654

\section{Check for updates}

\section{Copyright}

(c) VNU-HCM Press. This is an openaccess article distributed under the terms of the Creative Commons Attribution 4.0 International license.

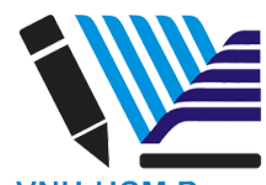

VNU-HCM Press

\begin{abstract}
The booming of E-commerce trading sites, especially after COVID-19, has aggressively put pressure on the competition in this industry. Hence, building young customers' loyalty plays a vital role in doing business. One of the best solutions to this problem is to boost customer satisfaction. As customers are satisfied with the products or services provided, they tend to purchase more frequently and eventually become more loyal. Regarding location, HCM City is currently the most potential market for E-commerce development. Therefore, the aim of this paper is to weigh the relative impacts of customer satisfaction factors on the youth's loyalty (18-25 years old) to E-commerce trading sites in HCM City, address the existing issues, and propose the corresponding solutions. The study used Multiple Linear Regression Analysis with SPSS 20.0 to build, examine, and test the research model. Through 215 samples, five factors are identified to affect the youth's loyalty. They are the satisfaction with website design, the satisfaction with the product portfolio, the satisfaction of privacy \& security, the satisfaction of delivery, and the satisfaction of post-sales service. The results reveal that the satisfaction of privacy \& security is the most influential factor on the youth's loyalty, followed by the satisfaction of post-sales service and the satisfaction of website design. In addition, there are no differences in young customers' loyalty regardless of genders, occupations, frequencies of visiting E-commerce sites, monthly income levels, and average spending per order. Accordingly, these findings can be good guidance for E-commerce trading sites to formulate suitable development strategies to build the loyalty of customers at the early stage (18-25 years old) and effectively compete in the market. On the other hand, the paper has certain limitations, namely the short duration of collecting primary data (one month) and thus the relatively small sample size compared to the whole population of the youth. Moreover, as the method of data collection is survey-based, the study must be remade for different regions and nations. Also, this paper only covers E-commerce trading sites within the retailing industry. Hence, future research can greatly improve the model by extending the time period of data collection and covering more industries. Besides, a more modern approach such as SEM is a decent option for measurement scales evaluation and model testing, since Multiple Linear Regression Analysis requires strict assumptions and may have a great likelihood of measurement errors.
\end{abstract}

Key words: E-commerce trading floors, Satisfaction, Loyalty, The youth

\section{INTRODUCTION}

Although E-commerce still accounts for a modest share of retails in Vietnam, it is gaining increasing popularity among consumers, especially after COVID-19. Vietnam E-commerce Association estimates that after 10 years, E-commerce will constitute $10 \%$ of B2C sales, and Vietnam can even surpass Thailand in terms of the E-commerce market size. One inevitable contributor to this phenomenon is the growth of E-commerce trading sites with such preeminent names as Tiki.vn, Sendo.vn, Shopee.vn và Lazada.vn. However, the odds of customers returning to offline shopping remain very high. Therefore, how to create and maintain customer loyalty to E-commerce trading sites is of urgent need, particularly among the youth (18-25 years old) who are considered as the consumers of the future.

A number of studies have been conducted on customer loyalty to E-commerce worldwide. The three most widely accepted determinants are satisfaction, trust, and commitment, in which satisfaction has proven itself as the most prominent ${ }^{1}$. To analyze further the impact of satisfaction on loyalty, many researchers have adopted the SERVQUAL model and assessed satisfaction in terms of E-commerce features. Some of the suggested factors include website usability, technology adoption, convenience, safety and privacy, information quality, confidentiality, website improvement, order fulfillment, system readiness, etc. Unfortunately, most previous foreign frameworks fail to conduct qualitative research and thus neglect other important satisfaction elements. Moreover, their 
findings are solely applicable to the $\mathrm{B} 2 \mathrm{C}$ E-commerce environment, whereas $\mathrm{C} 2 \mathrm{C}$ settings - which are now thriving in Vietnam - are rarely mentioned.

Concerning domestic research, since E-commerce is still a new emerging industry in Vietnam, empirical studies on satisfaction and loyalty in the context of online shopping are quite limited. A typical example of E-commerce loyalty research is ${ }^{2}$ conducted by Nguyen Thi Nhu Hoa and Nguyen Thao Nguyen. However, independent variables were developed generally, causing huge difficulties for E-commerce platforms to apply in reality. Therefore, the objective of this study is to discover, build, and test the measurement scales of specific satisfaction factors that influence customer loyalty to E-commerce trading sites. The scope is limited to opinions of the youth from 18 to 25 years old in HCM City, where E-commerce is most thriving in Vietnam ${ }^{3}$. The process of collecting data, interviewing and surveying took place from February 2020 to March 2020.

In brief, from the theoretical viewpoint, this study firstly helps to enrich the limited portfolio of domestic papers on the E-commerce satisfaction-loyalty relationship. Also, the factors are specifically identified rather than generally conceptualized for effective implementation. In comparison with foreign research, it is the comprehensive integration of most satisfaction-loyalty models, based not only on the classic SERVQUAL framework but also on the qualitative study to fit the current development of Vietnam and shopping preference of the youth (18-25 years old). More importantly, the findings are true for both B2C and C2C E-commerce trading sites, thus offering more flexibility for application.

The next sections of the paper include (1) Literature review and theoretical framework, (2) Methodology,

(3) Results and Discussions, (4) Conclusions and policy implications.

\section{LITERATURE REVIEW, THEORETICAL FRAMEWORK}

\section{Satisfaction with website design}

Website is the direct confrontation of an E-commerce platform with its customers. Wang et al. believe that this factor reflects the competence of E-commerce websites and hence induces satisfaction ${ }^{4}$. Inevitably, the very first step to encourage online shopping is to build an easy-to-use website with a well-organized display, eye-catching visualization, sufficient system availability, great ease of navigation, and simple order procedure. Furthermore, Safa and Ismail suggest that customization is also a very important element of website design ${ }^{5}$. Since the later generations are more craving for personalization in every aspect of their daily lives, an E-commerce site that tailors the offered products and services in accordance with customer needs gains customer satisfaction, as well as intentions to repurchase. Hence, the first hypothesis is proposed as follows:

Hypothesis H1: The factor "Customer satisfaction of website design" positively affects the youth's loyalty.

\section{Satisfaction with the product portfolio}

In essence, an E-commerce trading site is an online marketplace or a middleman that connects individuals/organizations and consumers, providing connecting services rather than selling its goods. However, the satisfaction of the product portfolio is still a suitable independent variable in this research, because customers tend to be more loyal when they acknowledge that their varied needs can always be fulfilled due to the large number of goods sold on E-commerce trading sites. As a result, online shoppers are more inclined to revisit E-commerce platforms that offer more purchasing options ${ }^{6}$. Cho and Park also found similar findings on the importance of the product portfolio to customer satisfaction ${ }^{7}$. Hence, the second hypothesis is suggested as follows:

Hypothesis H2: The factor "Customer satisfaction of the product portfolio" positively affects the youth's loyalty.

\section{Satisfaction with privacy \& security}

Privacy relates to the protection of customers' data during their online interaction with E-commerce websites, while security refers to the protection of the whole website system and any associated information from outsiders or non-permissive invasions. Inarguably, privacy \& security are vital measurements in online retailing services ${ }^{8}$. Online purchases are risky as shoppers can neither check product quality nor monitor personal information. According to Vietnam E-commerce White Book 2019, the fear of having personal data abused ranked the 3 rd of all barriers to online shopping ${ }^{9}$. Despite the technical advancements in Internet security such as cryptography, digital signatures, and certificates, online customers are still concerned with security issues in the shopping experience. Therefore, if any E-commerce platform can prove itself as a safe website for a customer to make a transaction, customers will be more likely to re-purchase on that page. Hence, the third hypothesis is suggested as follows:

Hypothesis H3: The factor "Customer satisfaction of privacy \& security" positively affects the youth's loyalty. 


\section{Satisfaction with delivery}

For the success of online retail, delivery plays a critical role as it ranks the fourth regarding online shopping concerns". Ramanathan believes that "significant sources of customer dissatisfaction arises either due to late arrival (or non-arrival) of the product, accuracy of the order and/or damaged products" ${ }^{10}$. Thus, delivery can be assessed through transport possibilities, time, speed, flexibility, and handling. Inevitably, along with the high growth rate of E-commerce, last year Vietnam witnessed the rapid development and fierce competition of last-mile delivery services. Hence, the fourth hypothesis is suggested as follows:

Hypothesis H4: The factor "Customer satisfaction of delivery" positively affects the youth's loyalty.

\section{Satisfaction with post-sales service}

Post-sales service or customer service can be understood as the non-monetary aspect of a product. Its existence ensures the expectations of customers are met or even surpassed. As a result, post-sales service has a significant impact on customer satisfaction ${ }^{10}$. However, unlike other traditional stores or eretailers that sell their own goods on their websites, E-commerce trading sites function as marketplaces and thus are not compulsorily responsible for handling complaints or answering questions about products. Consequently, other aspects of post-sales service are examined, namely product returns \& refunds, and customer reviews. $47 \%$ online consumers in Vietnam are concerned with returns \& refunds policies, while customer review is considered as the No.1 reason that encourages customers to purchase on a particular platform ${ }^{9}$. Hence, the fifth hypothesis is suggested as follows:

Hypothesis H5: The factor "Customer satisfaction of the post-sales service" positively affects the youth's loyalty.

\section{Customer loyalty}

The importance of customer loyalty has long been realized in literature. According to Oliver, customer loyalty is the strong commitment of customers to make perpetual purchases regardless of marketing efforts from other brands ${ }^{11}$. A loyal customer is committed and willing to purchase more in both quantity and frequency, and most importantly, not easily switched to other alternatives or more attractive options ${ }^{5}$. Thus, customer loyalty is one of the most important assets of any business to succeed. Since it is most affected by customer satisfaction ${ }^{1}$, a deep understanding of satisfaction on the youth's loyalty will help E-commerce flourish further.

Based on foreign and domestic empirical research, as well as focus group interview, the following model of the satisfaction-loyalty relationship on E-commerce trading sites is suggested (Figure 1).

\section{METHODOLOGY}

\section{Qualitative research}

Qualitative research is conducted through a focus group discussion of 7 customers aged from 18-25 years old who are currently shopping on E-commerce trading sites. There are three main objectives of this interview method: (1) evaluate the suitability of the proposed elements, (2) remove factors that are initially included in the model but unfeasible to assess in practice, (3) discover other potential factors.

Results reveal that all satisfaction elements affecting the youth's loyalty belong to the 5 suggested determinants (the satisfaction of website design, the satisfaction of the product portfolio, the satisfaction of privacy \& security, the satisfaction of delivery, and the satisfaction of the post-sales service). Moreover, the focus group interview also further suggests five additional items for the satisfaction of privacy \& security, the satisfaction of delivery, and the satisfaction of post-sales service, thus making the research model more comprehensive.

\section{Quantitative research}

Based on qualitative results and empirical research, the measurement scales for each variable are built. As the nature of the study is online, Google Form is used to create the questionnaire with the Likert scale of 1 to 5 , in which 1 means "Strongly disagree" and 5 means "Strongly agree". Herein, random sampling is applied. The survey is first tested by 20 respondents and only one observed item needs to be changed for better understanding (WD3: changed from "I can easily navigate myself on the website while browsing" to "I can easily find the information or products I need"). Hence, no variables are removed. The next step is the implementation of the official research to reaffirm the significance of variables, the reliability of measurement scales, and thus the validity of the research model. In this step, Cronbach's Alpha reliability analysis, Exploratory Factor Analysis (EFA), Pearson's Correlation Coefficient Analysis and Multiple linear regression analysis, as well as one-way ANOVA test and ttest analysis, are implemented.

The sample size for the research model is calculated based on the formula: $n \geq 8 m+50$, with $n$ being the 


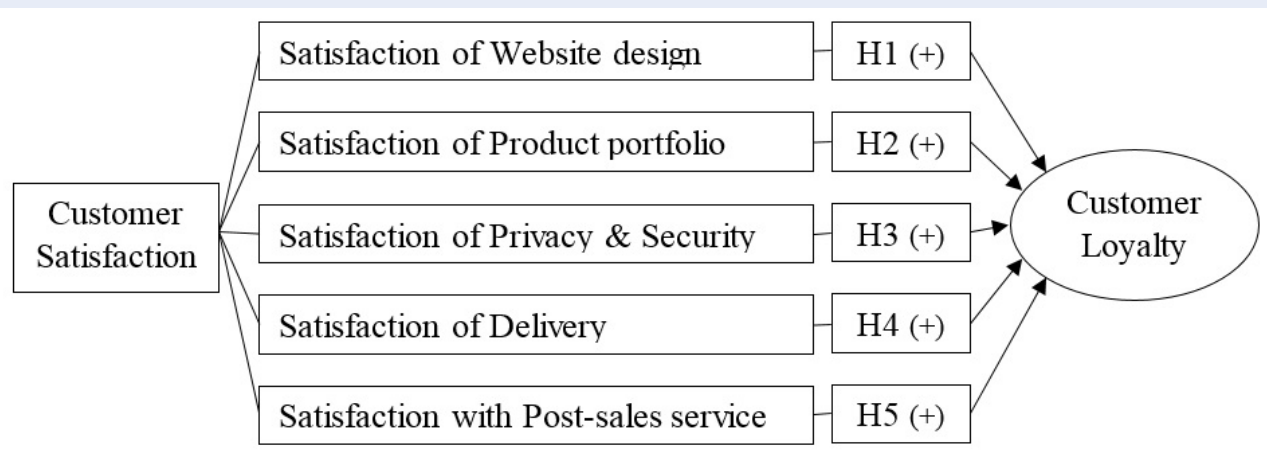

Figure 1: Proposed theoretical research model ${ }^{a}$

a (Source: collected by the author)

sample size and $\mathrm{m}$ being the number of independent variables $^{12}$. Thus, with 5 satisfaction factors, the minimum number for sampling is 90 . Additionally, Hair et al. suggest that for every independent observed item, at least 5 samples are needed to ensure the representativeness and reliability for the sampling itself and $\mathrm{EFA}^{13}$. Consequently, with 23 independent observed items in the research model, the sample size must be at least $23 \times 5=115$ samples. Overall, 215 responses are collected, which is well sufficient for sampling. Regarding gender, females account for $62.8 \%$ while males constitute $37.2 \%$. Regarding occupation, there are $70.2 \%$ of students and $29.8 \%$ of the employed. Regarding monthly income, $51.2 \%$ earn below 5 million VND, 23.3\% earn 6-10 million VND, 17.2\% earn 11-15 million VND, and the rest earn above 15 million VND. However, in terms of average spending per order, 200,000-500,000 VND accounts for the most share, with $55.8 \%$, while below 200,000 VND represents $32.1 \%$.

\section{RESULTS AND DISCUSSION}

\section{Cronbach's Alpha analysis}

In this research, the reliability of the measurement scales is assessed by Cronbach's Alpha analysis. It is the most widely used method that tests the consistency and correlation among observed items. Its value ranges from 0 to 1 , and the higher the coefficients, the greater reliability of the measurement scales. There are two criteria for this analysis: (1) Cronbach's Alpha of total scale $\geq 0.6$ and (2) the Corrected Item Total correlation coefficient $\geq 0.3^{14}$.

In theory, another important indicator is Cronbach's Alpha if Item Deleted. Since a more reliable measurement scale is more desirable, any item with Cronbach's Alpha if Item Deleted larger than the total
Cronbach's Alpha should be considered for elimination. However, the removal of that item can only be confirmed by the EFA results.

Table 1 reveals that all items meet the requirements. Although PP3 and CL3 have Cronbach's Alpha if Item Deleted larger than the overall Cronbach's Alpha, they will not be eliminated unless EFA analysis is not satisfied. Thus, all the observed items are qualified to be kept in the model.

\section{Exploratory Factor Analysis (EFA)}

EFA aims to convert a set of many independent variables into a smaller set so that they are more meaningful but still contain most of the information of the original set. In this research, the Principal Components extraction method and Varimax rotation are applied. There are 5 criteria: (1) $0.5 \leq \mathrm{KMO} \leq 1$; (2) Barlett's test has statistical significance (Sig. < 0.05); (3) Only keep the variables with Eigenvalue not less than 1.0 ; (4) Total variance explained is greater than 50\%; (5) Factor loading $\geq 0.5^{15}$. Also, EFA is conducted separately between dependent variables and independent variables, as the model has clearly distinguished these two types of variables ${ }^{13}$.

\section{EFA with independent variables}

Results show that $\mathrm{KMO}=0.887(>0.5$ and $<1)$; Barlett's test has Sig. $=0.000<0.05$, proving EFA is appropriate. At Eigenvalue $=1.049>1$, a total of 5 factors are extracted from 23 observed items, which is equal to the number of satisfaction factors suggested in the research model. Total variance explained is $58.403 \%$ $>50 \%$. Additionally, all factor loadings range from 0.511 to $0.791(\geq 0.5)$. In brief, the observed items in the suggested model have satisfied the EFA criteria, and thus PP3 will not be eliminated. 
Table 1: Cronbach's Alpha analysis results

\begin{tabular}{|c|c|c|c|c|}
\hline Observed variables & $\begin{array}{l}\text { Scale Mean if Item } \\
\text { Deleted }\end{array}$ & $\begin{array}{l}\text { Scale Variance if } \\
\text { Item Deleted }\end{array}$ & $\begin{array}{l}\text { Corrected Item- } \\
\text { Total Correlation }\end{array}$ & $\begin{array}{l}\text { Cronbach's Alpha if } \\
\text { Item Deleted }\end{array}$ \\
\hline \multicolumn{5}{|c|}{ Satisfaction of website design: Cronbach's Alpha $=\mathbf{0 . 8 2 6}$} \\
\hline WD1 & 19.14 & 9.289 & 0.649 & 0.789 \\
\hline WD2 & 19.17 & 8.900 & 0.641 & 0.789 \\
\hline WD3 & 18.88 & 8.995 & 0.660 & 0.785 \\
\hline WD4 & 19.20 & 8.967 & 0.530 & 0.815 \\
\hline WD5 & 18.94 & 9.104 & 0.612 & 0.795 \\
\hline WD6 & 18.76 & 9.745 & 0.499 & 0.817 \\
\hline \multicolumn{5}{|c|}{ Satisfaction of product portfolio: Cronbach's Alpha $=0.646$} \\
\hline PP1 & 6.69 & 2.159 & 0.444 & 0.574 \\
\hline PP2 & 6.98 & 1.761 & 0.553 & 0.414 \\
\hline PP3 & 7.66 & 1.713 & 0.398 & 0.656 \\
\hline \multicolumn{5}{|c|}{ Satisfaction of privacy \& security: Cronbach's Alpha $=\mathbf{0 . 7 8 8}$} \\
\hline PS1 & 13.82 & 6.913 & 0.492 & 0.772 \\
\hline PS2 & 13.86 & 6.171 & 0.532 & 0.765 \\
\hline PS3 & 13.85 & 6.697 & 0.620 & 0.734 \\
\hline PS4 & 13.74 & 6.359 & 0.622 & 0.730 \\
\hline PS5 & 13.69 & 6.662 & 0.588 & 0.742 \\
\hline \multicolumn{5}{|c|}{ Satisfaction of delivery: Cronbach's Alpha $=0.817$} \\
\hline DL1 & 18.43 & 9.124 & 0.612 & 0.781 \\
\hline DL2 & 18.52 & 9.092 & 0.612 & 0.781 \\
\hline DL3 & 18.62 & 8.443 & 0.632 & 0.776 \\
\hline DL4 & 18.51 & 9.055 & 0.592 & 0.785 \\
\hline DL5 & 18.42 & 9.544 & 0.513 & 0.802 \\
\hline DL6 & 18.66 & 9.207 & 0.525 & 0.800 \\
\hline \multicolumn{5}{|c|}{ Satisfaction of post-sales service: Cronbach's Alpha $=\mathbf{0 . 7 5 6}$} \\
\hline AS1 & 6.91 & 2.464 & 0.519 & 0.748 \\
\hline AS2 & 6.93 & 1.598 & 0.654 & 0.604 \\
\hline AS3 & 6.86 & 2.096 & 0.618 & 0.639 \\
\hline \multicolumn{5}{|c|}{ Customer loyalty: Cronbach's Alpha $=\mathbf{0 . 7 2 2}$} \\
\hline CL1 & 10.54 & 3.791 & 0.458 & 0.691 \\
\hline CL2 & 10.60 & 3.297 & 0.647 & 0.585 \\
\hline CL3 & 11.32 & 3.488 & 0.351 & 0.776 \\
\hline CL4 & 10.64 & 3.184 & 0.646 & 0.580 \\
\hline
\end{tabular}

(Source: collected by the author) 


\section{EFA with dependent variables}

Like independent variables, the dependent variable customer loyalty - also fulfils all the five requirements. In particular: $\mathrm{KMO}=0.697(>0.5$ and $<1)$; Barlett's test has Sig. $=0.000<0.05$; Eigenvalue $=2.276>1$ with one variable extracted, matching with one suggested dependent variable in the research model; Total variance explained is $56.889 \%>50 \%$; and factor loadings are larger than 0.5 . Therefore, the measurement scale for customer loyalty is appropriate, and CL3 is not necessarily removed from the model.

\section{Pearson's Correlation Coefficient Analysis}

Another important analysis before conducting regression is Pearson's Correlation Coefficient Analysis. It is used to measure the correlation degree between independent and dependent variables, then only independent elements that correlate with the dependent variable are chosen and put in regression. Its value ranges from +1 to -1 , representing the characteristics of the relationship between items (positive/none/negative). There is only one criterion for this analysis: Sig. < 0.05 .

For ease of calculation, all 27 observed variables are classified into six corresponding independent and dependent variables whose values are the average of smaller component items. Table 2 indicates that all Pearson's Correlation Coefficients are significant at the $1 \%$ level. Thus, the requirement for this analysis is met. Also, with 0.540 , the satisfaction of privacy \& security has the highest correlation with the youth's loyalty, meaning the youth's loyalty increases the most when the satisfaction of privacy \& security increases. In contrast, the lowest correlation with the youth's loyalty belongs to the satisfaction of the product portfolio with 0.475 .

\section{Multiple Linear Regression Analysis}

Regression analysis is a popular statistical technique used to analyze the relationship between dependent and independent variables. The larger beta coefficient a factor has, the more influential that factor is on the youth's loyalty.

Table 3 shows that not only do all Betas have statistical significance at 5\% level, but they are also positive, meaning all the five satisfaction factors have positive relationships with the youth's loyalty. More specifically, the satisfaction of privacy \& security is proven to be the most influential with the highest coefficient of 0.191 , followed by the satisfaction of the post-sales service and the satisfaction of website design. Thus, the linear regression function of this model is as follows:
$\mathrm{CL}=0.178 \mathrm{WD}+0.146 \mathrm{PP}+0.191 \mathrm{PS}+0.145 \mathrm{DL}+$ 0.180AS

However, the model is only validated if the following hypotheses are examined.

\section{Hypothesis on the appropriateness of the model}

To test the appropriateness of the regression model, the coefficients of adjusted $\mathrm{R}$ square and DurbinWatson value must be checked. Table 4 reveals that the adjusted $\mathrm{R}$ square of the model is 0.404 , meaning the five satisfaction variables can explain $40.4 \%$ of changes in the youth's loyalty.

Regarding the Durbin-Watson coefficient, it is used to check the autocorrelation problem in the residuals of the regression analysis. In principle, the model is appropriate when it has no autocorrelation - in other words, the Durbin-Watson coefficient must be larger than 1 but smaller than 3 . Table 4 reveals that the achieved Durbin-Watson coefficient is 2.005 , thereby justifying the suitability of the model.

\section{Hypothesis on the population fitness of re- gression model}

Although the suggested model is proven to be appropriate, it is only true to the sampled data but not to the whole real population. Therefore, in order to verify the appropriateness of the model to the whole population, F-test in ANOVA analysis is required. According to Table 5, the significance level of the F-test is 0.000 , lower than 0.05 . Thus, the criterion is met.

\section{Hypothesis on the statistical significance of linear regression}

The linear regression analysis is conducted based on certain assumptions regarding multicollinearity, the residuals' normal distribution, and the linear relationship. If any of these presumptions collapses, the model loses its statistical significance.

Assumption of no multicollinearity

To verify the presence of multicollinearity, the examination of VIF is mandatory. In theory, VIF $<10$ is sufficient to indicate that the model experiences no multicollinearity ${ }^{15}$. However, the requirement is much stricter in practice, demanding VIF $<2$ especially for models that use Likert measurement. Table 3 shows that there are no VIF values larger than 2; hence, the assumption of no multicollinearity is satisfied. 
Table 2: Pearson's Correlation Coefficient Analysis

\begin{tabular}{|c|c|c|c|c|c|c|c|}
\hline & & CL & WD & PP & PS & DL & AS \\
\hline \multirow[t]{2}{*}{ CL } & $\begin{array}{l}\text { Pearson Correla- } \\
\text { tion }\end{array}$ & 1 & $0.483^{* *}$ & $0.475^{\star *}$ & $0.540^{* *}$ & $0.509^{* *}$ & $0.477^{* *}$ \\
\hline & Sig. (2-tailed) & & 0.000 & 0.000 & 0.000 & 0.000 & 0.000 \\
\hline \multirow[t]{2}{*}{ WD } & $\begin{array}{l}\text { Pearson Correla- } \\
\text { tion }\end{array}$ & $0.483^{* *}$ & 1 & $0.476^{\star *}$ & $0.513^{* *}$ & $0.541^{\star *}$ & $0.326^{\star *}$ \\
\hline & Sig. (2-tailed) & 0.000 & & 0.000 & 0.000 & 0.000 & 0.000 \\
\hline \multirow[t]{2}{*}{ PP } & $\begin{array}{l}\text { Pearson Correla- } \\
\text { tion }\end{array}$ & $0.475^{\star *}$ & $0.476^{* *}$ & 1 & $0.530^{\star *}$ & $0.470^{* *}$ & $0.416^{* *}$ \\
\hline & Sig. (2-tailed) & 0.000 & 0.000 & & 0.000 & 0.000 & 0.000 \\
\hline \multirow[t]{2}{*}{ PS } & $\begin{array}{l}\text { Pearson Correla- } \\
\text { tion }\end{array}$ & $0.540^{\star *}$ & $0.513^{\star *}$ & $0.530^{\star *}$ & 1 & $0.562^{* *}$ & $0.547^{\star *}$ \\
\hline & Sig. (2-tailed) & 0.000 & 0.000 & 0.000 & & 0.000 & 0.000 \\
\hline \multirow[t]{2}{*}{ DL } & $\begin{array}{l}\text { Pearson Correla- } \\
\text { tion }\end{array}$ & $0.509^{* *}$ & $0.541^{* *}$ & $0.470^{* *}$ & $0.562^{\star *}$ & 1 & $0.511^{\star *}$ \\
\hline & Sig. (2-tailed) & 0.000 & 0.000 & 0.000 & 0.000 & & 0.000 \\
\hline \multirow[t]{2}{*}{ AS } & $\begin{array}{l}\text { Pearson Correla- } \\
\text { tion }\end{array}$ & $0.477^{\star *}$ & $0.326^{* *}$ & $0.416^{\star *}$ & $0.547^{\star *}$ & $0.511^{* *}$ & 1 \\
\hline & Sig. (2-tailed) & 0.000 & 0.000 & 0.000 & 0.000 & 0.000 & \\
\hline
\end{tabular}

Table 3: Multiple linear regression analysis result

\begin{tabular}{|c|c|c|c|c|c|c|c|c|}
\hline \multirow[t]{2}{*}{ Model } & & \multicolumn{2}{|c|}{$\begin{array}{l}\text { Unstandardized Coef- } \\
\text { ficients }\end{array}$} & $\begin{array}{l}\text { Standardiz } \quad t \\
\text { Coeffi- } \\
\text { cients }\end{array}$ & t & \multirow[t]{2}{*}{ Sig. } & \multicolumn{2}{|c|}{ Collinearity Statistics } \\
\hline & & B & $\begin{array}{l}\text { Std. Er- } \\
\text { ror }\end{array}$ & Beta & & & Tolerance & VIF \\
\hline \multirow[t]{6}{*}{1} & Constant & 0.728 & 0.241 & & 3.020 & 0.003 & & \\
\hline & WD & 0.177 & 0.067 & 0.178 & 2.642 & 0.009 & 0.611 & 1.637 \\
\hline & PP & 0.137 & 0.062 & 0.146 & 2.202 & 0.029 & 0.634 & 1.576 \\
\hline & PS & 0.181 & 0.070 & 0.191 & 2.586 & 0.010 & 0.509 & 1.966 \\
\hline & $\mathrm{DL}$ & 0.145 & 0.072 & 0.145 & 2.013 & 0.045 & 0.539 & 1.856 \\
\hline & AS & 0.158 & 0.058 & 0.180 & 2.707 & 0.007 & 0.629 & 1.591 \\
\hline
\end{tabular}

(Source: collected by the author)

Table 4: Model summary of multiple linear regression analysis

\begin{tabular}{lllll}
\hline $\mathrm{R}$ & $\mathrm{R}$ Square & Adjusted R Square & Std. Error of the Estimate & Durbin-Watson \\
$0.647^{a}$ & 0.418 & 0.404 & 0.45649 & 2.005 \\
\hline
\end{tabular}

(Source: collected by the author) 
Table 5: F-test in ANOVA analysis

\begin{tabular}{|c|c|c|c|c|c|c|c|}
\hline Model & & $\begin{array}{l}\text { Sum } \\
\text { Squares }\end{array}$ & of & $\mathrm{df}$ & Mean Square & $\mathrm{F}$ & Sig. \\
\hline \multirow[t]{3}{*}{1} & Regression & 31.321 & & 5 & 6.264 & 30.060 & 0.000 \\
\hline & Residual & 43.553 & & 209 & 0.208 & & \\
\hline & Total & 74.873 & & 214 & & & \\
\hline
\end{tabular}

(Source: collected by the author)

Assumptions of the residuals' normal distribution

In this paper, the Histogram frequency chart for surveying the distribution of residuals is applied. In theory, the normal distribution must have Mean $=0$ and standard deviation $=1$. Figure 2 reveals that the model has Mean $=-9.57 \mathrm{E}-16$, approximately equal to 0 , and Standard deviation $=0.968$, close to 1 . Moreover, it also witnesses a bell-shaped curve, which is typical of normal distribution. Consequently, the assumption of the residuals' normal distribution is supported.

\section{Assumption of the linear relationship}

In this paper, a Scatterplot between regression standardized residual and regression standardized predicted value is applied. Figure 3 indicates that regression standardized residual does not systematically change in accordance with regression standardized predicted value. In other words, the residuals diffuse randomly in the coordinate area around the vertical line $y=0$. Consequently, the assumption of the linear relationship is supported.

\section{The impact of demographic variables on the satisfaction-customer relationship}

To examine how demographic variables affect the impact of customer satisfaction on the youth's loyalty, an independent t-test and one-sample ANOVA test are used. For such variables with only 2 values as gender and occupation, the independent t-test is preferred. On the other hand, for variables with at least 3 values, namely the frequency of visiting E-commerce sites, monthly income, and average spending per order, one-sample ANOVA test is more favored.

\section{By gender with independent $t$-test}

Results show that the significance level of Levene's test is 0.074 , greater than 0.05 , which means that variances between two genders are not different. Then, the significance of the t-test in the equal variances assumed row is considered. With the value of 0.329 , it exceeds 0.05. Thus, there is no statistical discrepancy in the impact of customer satisfaction on the youth's loyalty by gender.

\section{By occupation with independent t-test}

Like gender, occupation has the significance level of Levene's test which is larger than 0.05 (Sig. $=0.627$ ), which means that variances between students and the employed are not diverse. Also, the significance of the $\mathrm{t}$-test in the equal variances assumed row is 0.594 , much bigger than 0.05 . Hence, there is no statistical discrepancy in the impact of customer satisfaction on the youth's loyalty regarding occupation.

\section{By frequency of visiting E-commerce sites with ANOVA test}

The frequency of visiting E-commerce trading sites is divided into 5 groups - only big sales, once every 2 weeks, 1-2 times/week, 3-5 times/week, and every day. Results show that both significance levels of Levene' test and ANOVA test are larger than 0.05, with the values of 0.100 and 0.070 respectively. Thus, there is no statistical difference in the impact of customer satisfaction on the youth's loyalty in terms of the frequency of visiting E-commerce sites.

\section{By monthly income with ANOVA test}

The demographic variable "monthly income" consists of 4 categories: below 5 million VND, 5-10 million VND, 10-15 million VND, and over 15 million VND. Results point out that both significance levels of Levene' test and ANOVA test are larger than 0.05, with the values of 0.579 and 0.166 respectively. Thus, there is no statistical difference in the impact of customer satisfaction on the youth's loyalty regarding monthly income.

\section{By average spending per order with ANOVA test}

Average spending per order is classified into 4 ranges: below 200,000 VND, from 200,000 VND to 500,000 VND, from 500,000 VND to 1 million VND, and over 1 million VND. Results point out that both significance levels of Levene' test and ANOVA test are larger 


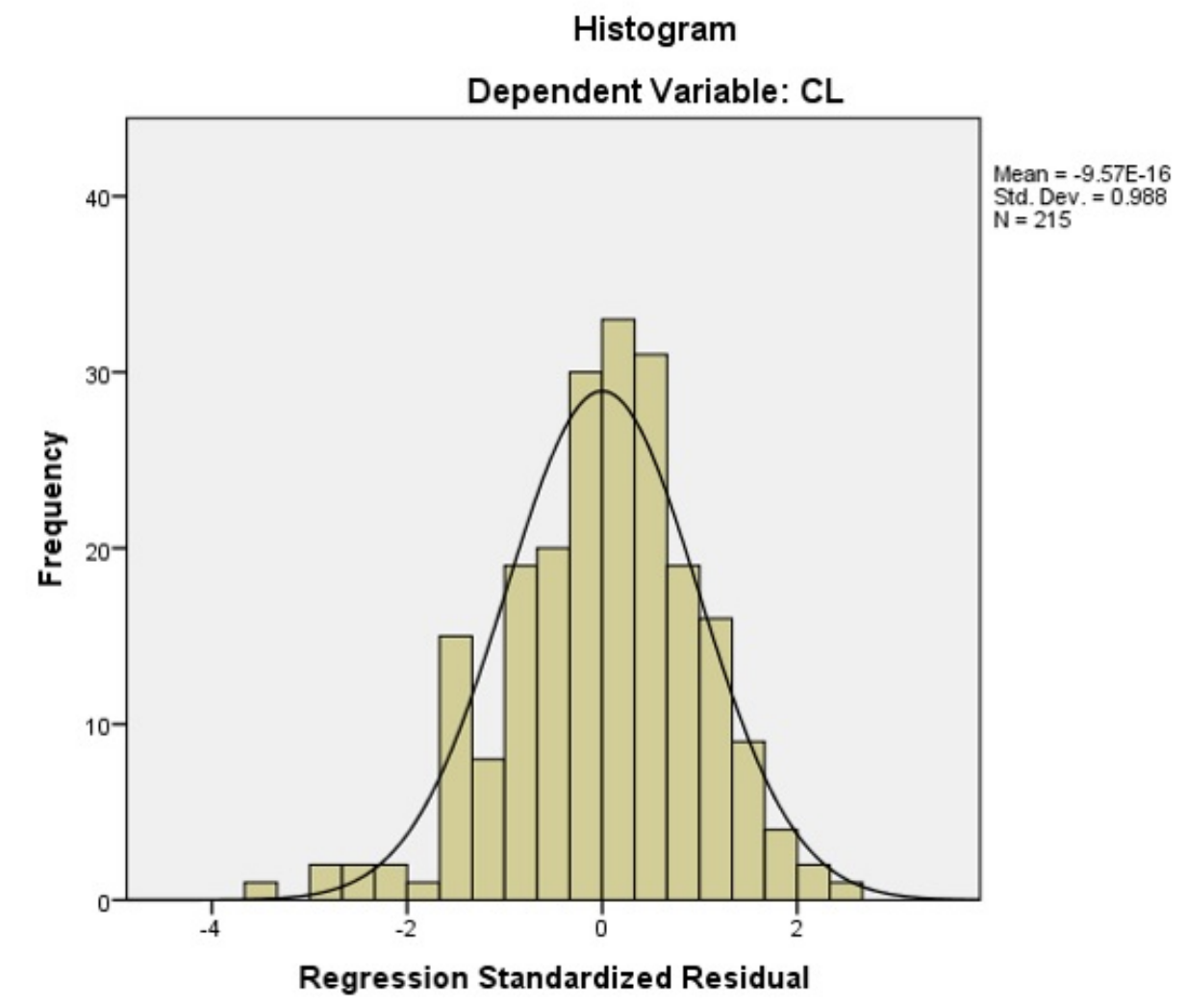

Figure 2: Histogram frequency chart for surveying distribution of residuals ${ }^{a}$

${ }^{a}$ (Source: collected by the author)

than 0.05 , with the values of 0.312 and 0.164 respectively. Thus, there is no statistical difference in the impact of customer satisfaction on the youth's loyalty with regards to average spending per order.

\section{CONCLUSIONS AND POLICY IMPLICATIONS}

The impact of satisfaction on customer loyalty towards E-commerce trading floors

Regression analysis indicates that all hypotheses 1-5 on the satisfaction-loyalty relationship are supported, proving the five suggested satisfaction factors have statistically significant and positive relationships with the youth's loyalty. The satisfaction of privacy \& security plays the leading role in the enhancement of the youth's loyalty, followed by the satisfaction of the post-sales service and the satisfaction of website design. The least influential factor is the satisfaction of delivery.

Additionally, such findings are in line with previous research. In specific, website design and privacy \& se- curity are also both found statistically important in ${ }^{16}$ and ${ }^{17}$. The satisfaction of the product portfolio was first introduced in ${ }^{6}$ and is proven in this study to influence the youth's loyalty to E-commerce. Delivery is a special dimension as it is suggested in the research model based on the literature review, particularly from ${ }^{18}$ and ${ }^{10}$. Due to the collected data, the paper has verified the importance of delivery in the E-commerce satisfaction-loyalty relationship. For the final factor - the satisfaction of post-sales service, it is also confirmed to statistically affect the youth's loyalty to E-commerce, as previously proven in ${ }^{10}$.

The impact of demographic variables on the satisfaction-customer relationship

Another meaningful finding in this research is that there is no statistical disparity in the impact of customer satisfaction on the youth's loyalty between groups regardless of genders, occupations, frequencies of visiting E-commerce sites, monthly income levels, and average spending per order. Such a con- 


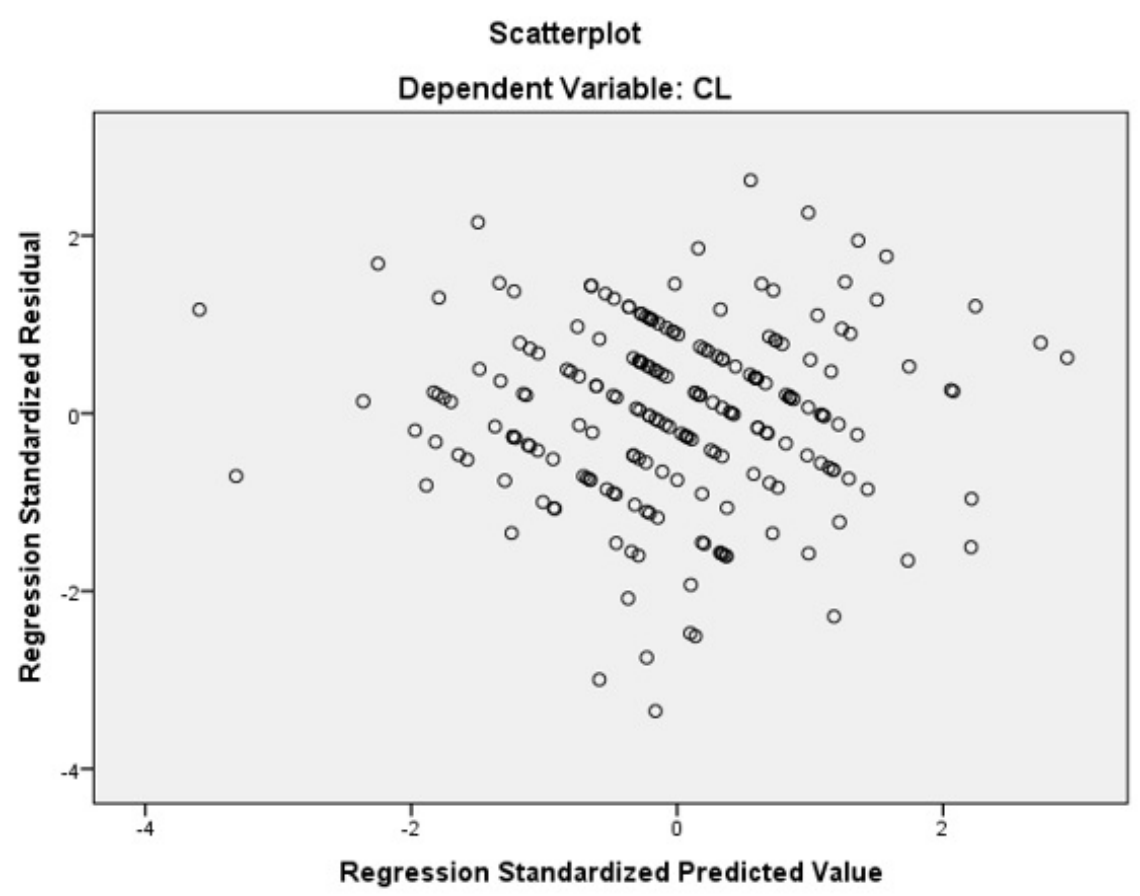

Figure 3: Scatterplot between regression standardized residual and regression standardized predicted value ${ }^{a}$

${ }^{a}$ (Source: collected by the author)

clusion is compatible with that from ${ }^{19}$.

\section{Suggestions for E-commerce trading floors}

Among the five satisfaction factors, the satisfaction of privacy \& security exerts the strongest impact on the youth's loyalty. Indeed, the fear of leaking personal information and insecure systems is still one of the biggest barriers to online shopping in general and E-commerce trading sites in specific. Suggestions include: (1) readable and easy-to-understand privacy \& security policies located at an easy-to-find tab on the website, (2) increasing the number of trustworthy retailers, (3) secure the website with the SafeWeb certification.

The second influential factor is the satisfaction of the post-sale service. Suggestions include (1) understandable and easy-to-read product returns \& refund policies. Due to the lack of contact, the odds of receiving incorrect, flawed, or damaged goods are much higher in the online environment than those in the traditional settings. Therefore, great ease of product returns \& refunds would create more convenience for customers when such a problem arises; (2) extend the period of returns than one week maximum; (3) pro- mote the active review section; (4) boost more attractive incentives like free-shipping service.

The third influential factor is the satisfaction of website design. Suggestions include: (1) improve the website interface (well-organized, user-friendly with eyecatching visualization and smooth animation); (2) personalized websites; (3) ensure 24/7 system availability.

The fourth influential factor is the satisfaction of the product portfolio. Suggestions include: (1) diversify product categories with competitive prices offered; (2) ensure the availability of products; (3) double-check sellers' reputation so that product information is clear, accurate, up-to-date, relevant, and understandable.

The final factor is the satisfaction of delivery. Suggestions include: (1) offer more options for fast delivery; (2) increase the delivery speed; (3) ensure on-time delivery with the right products; (4) invest in ordertracking technology.

\section{Policy implications}

Although E-commerce in Vietnam has achieved outstanding growth compared to other nations in the Southeast Asia region, online shopping still bears 
many risks that no individual E-commerce company can solve alone. Therefore, the intervention of government authorities is extremely necessary. Recommendations include: (1) improve infrastructure, namely telecommunications and transaction security systems; (2) update laws in accordance with the current E-commerce development (tax policies, intellectual property rights, consumers' interests like privacy and dispute settlement, etc.); (3) support businesses with website building and develop E-commerce associations; (4) encourage auxiliary industries, namely last-mile logistics.

\section{Limitations and future research orientation}

Like most studies, this paper has certain limitations. First, the duration of collecting primary data is short (one month); thus, the obtained sample size covers only 215 respondents, which is relatively small compared to the total number of the youth from 18 to 25 years old who are currently shopping online on E-commerce sites. Therefore, in order to enhance the representativeness of the sample, further research should increase the amount of time to conduct the surveys.

Second, the method of data collection in this paper is survey-based. Thus, the research must be replicated when being applied to different regions and nations. Third, the study focuses mainly on only five major satisfaction factors (the satisfaction of website design, the satisfaction of the product portfolio, the satisfaction of privacy \& security, the satisfaction of delivery, and the satisfaction of the post-sales service) and assesses their relative impacts on the youth's loyalty. Inevitably, the results in regression analysis (namely, adjusted $\mathrm{R}$ square) show that there are other important elements that affect the youth's loyalty to Ecommerce. Moreover, the scope of this study is limited to E-commerce trading sites within the retailing industry. Therefore, further research can greatly improve the model by suggesting new crucial determinants and covering more industries.

Fourth, the multiple linear regression analysis used in this paper requires strict assumptions, thereby having a great likelihood of measurement errors. Hence, further research should apply a more novel and modern approach like SEM for the better evaluation of measurement scales and model testing.

\section{LIST OF ABBREVIATIONS}

ANOVA: Analysis Of Variance

B2C: Business to Consumer

C2C: Customer to Customer

E-commerce: Electronic commerce
EFA: Exploratory Factor Analysis

KMO: Kaiser-Meyer-Olkin

SEM: Structural Equation Modeling

SPSS: Statistical Package for Social Science

TP.HCM / HCM City: Ho Chi Minh City

USD: United States Dollar

VIF: Variance Inflation Factor

VND: Vietnam Dong

\section{CONFLICT OF INTEREST}

The authors whose names are listed immediately below certify that they have NO affiliations with or involvement in any organization or entity with any financial interest (such as honoraria; educational grants; participation in speakers' bureaus; membership, employment, consultancies, stock ownership, or other equity interest; and expert testimony or patent-licensing arrangements), or non-financial interest (such as personal or professional relationships, affiliations, knowledge or beliefs) in the subject matter or materials discussed in this manuscript.

Author names:

Nguyen Thi Quynh Nga

Do Hong Van

\section{AUTHORS' CONTRIBUTION}

The study makes four main contributions. Compared with foreign research, the framework is acomprehensive integration of satisfaction-loyalty models that goes beyond the classic SERVQUAL model by suggesting additional determinants through a focus on a group interview. Moreover, as the subject is E-commerce trading floors, its application is not restricted to $\mathrm{B} 2 \mathrm{C}$ settings but is further expanded to the $\mathrm{C} 2 \mathrm{C}$ environment. Also, the scope of the manuscript is among the youth, a digital-savvy and open-minded generation who is regarded as the consumers of the future. Concerning domestic research, the work helps enrich the limited portfolio of papers on E-commerce loyalty by specifically identifying the key satisfaction factors which were previously defined too broadly for E-commerce sites to efficiently apply in reality.

Nguyen Thi Quynh Nga and Do Hong Van together observe and research relevant models, propose suitable research approaches, finalize the research model, assess its feasibility and then recommend strategies for E-commerce trading floors and government authorities to foster E-commerce growth in Vietnam. In specific, Do Hong Van contributes the research methodology, model proposal, and data analysis. Nguyen Thi Quynh Nga contributes the research orientation, builds and modifies the measurement scales of the research model. 


\section{REFERENCES}

1. Pratminingsih S, Lipuringtyas C, Rimenta T. Factors influencing customer loyalty towards online shopping. International Journal of Trade, Economics and Finance. 2013;p. 104-110. Available from: https://doi.org/10.7763/IJTEF.2013.V4.268.

2. Hoa NTN, Nguyen NT. The relationship between transactional quality, relational quality and consumer e-loyalty. Yersin Journal of Science. 2018;4(1):3-16.

3. Vietnam E-commerce Association (VECOM). Vietnam EBusiness Index 2019 Report. [Online]. [Cited $2020 \mathrm{Jul}$ 31];Available from: https://www.vecom.vn/tai-lieu/bao-caochi-thuong-mai-dien-tu-viet-nam-2019.

4. Wang $Y$, Hernandez MD, Minor MS. Web aesthetics effects on perceived online service quality and satisfaction in an e-tail environment: The moderating role of purchase task. Journal of Business Research. 2010;63(9):935-942. Available from: https://doi.org/10.1016/j.jbusres.2009.01.016.

5. Safa NS, Ismail MA. A customer loyalty formation model in electronic commerce. Economic Modelling. 2013;35:559564. Available from: https://doi.org/10.1016/j.econmod.2013. 08.011.

6. Jiang L, Jun M, Yang Z. Customer-perceived value and loyalty: how do key service quality dimensions matter in the context of B2C e-commerce? Service Business. 2015;Available from: https://doi.org/10.1007/s11628-015-0269-y.

7. Cho N, Park S. Development of electronic commerce user-consumer satisfaction index (ECUSI) for Internet shopping. Industrial Management and Data Systems. 2001;101(8):400-405. Available from: https://doi.org/10.1108/EUM0000000006170.

8. Eid M. Determinants of e-commerce customer satisfaction, trust, and loyalty in Saudi Arabia. Journal of Electronic Commerce Research. 2011;12(1):78-93.
9. Vietnam E-commerce and Digital Economy Agency. Vietnam E-commerce White Book 2019. [Online]. Ministry of Industry and trade. [Cited 2020 Jul 31];Available from: http://idea.gov. vn/file/ef6314a6-709e-4d42-a2fa-b60457a66179.

10. Ramanathan R. An empirical analysis on the influence of risk on relationships between handling of product returns and customer loyalty in E-commerce. International Journal of Production Economics. 2011;(130):255-261. Available from: https://doi.org/10.1016/j.ijpe.2011.01.005.

11. Oliver RL. Satisfaction: a behavioural perspective on the consumer. New York: Irwin/ McGraw-Hill. 1997;p. 233.

12. Tabachnick BG, Fidell LS. Using Multivariate Statistics. 4th Edition. Boston: Allyn and Bacon. 2001;

13. Hair JF, Anderson RE, Tatham RL, Black WC. Multivariate Data Analysis. 5th Edition. New Jersey (USA): Prentice Hall. 1998;.

14. Nunnally JC. Psychometric theory. 2nd ed. New York: McGrawHill. 1978;p. 245.

15. Trong H, Ngoc CNM. Data analysis with SPSS. Ha Noi: Hong Duc Publishing House. 2008;.

16. Swaid SI, Wigand R. Key dimensions of e-commerce service quality and its relationships to satisfaction and loyalty. Proceedings of the 20th Bled Electronic Commerce Conference. 2007;p. 1-15.

17. Lin GTR, Sun CC. Factors influencing satisfaction and loyalty in online shopping: an integrated model. Online Information Review. 2009;33(3):458-475. Available from: https://doi.org/ 10.1108/14684520910969907.

18. Mašínová $V$, Švandová $Z$. Factors defining satisfaction and loyalty of the online shopping customers within e-commerce and cyber entrepreneurship. Proceedings of the 9th European Conference on Innovation \& Entrepreneu. Belfast, UK. 2014;p. 539.

19. Chien NQ, Thanh NTQ. Factors affecting customer loyalty towards online shopping. Journal of External Economics. 2017;92. 


\title{
Ảnh hưởng của sự hài lòng tới lòng trung thành của giới trẻ (18-25 tuổi) với sàn thương mại điện tử tại TP.HCM
}

\author{
Nguyễn Thị Quỳnh Nga ${ }^{*}$, Đỗ Hồng Vân
}

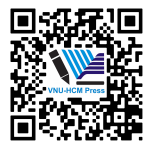

Use your smartphone to scan this QR code and download this article

Trường Đại học Ngoại thuiơng, Việt Nam

Liên hệ

Nguyễn Thị Quỳnh Nga, Trường Đại học Ngoại thương, Việt Nam

Email: nguyenthiquynhnga.cs2@ftu.edu.vn

Lịch sử

- Ngày nhận: 9/7/2020

- Ngày chấp nhận: 16/10/2020

- Ngày đăng: 16/11/2020

DOI :0.32508/stdjelm.v4i4.654

\section{Check for updates}

\section{Bản quyền}

๑ ĐHQG Tp.HCM. Đây là bài báo công bố mở được phát hành theo các điều khoản của the Creative Commons Attribution 4.0 International license.

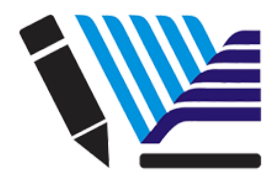

VNU-HCM Press

\section{TÓM TẮT}

Sự phát triển bùng nổ của sàn thương mại điện tử (TMĐT), đặc biệt sau COVID-19, khiến cuộc cạnh tranh trong ngành càng gay gắt. Do đó, xây dựng lòng trung thành của giới trẻ đóng vai trò rất quan trong. Một đề xuất phổ biến nhằm giải quyết vấn đề này là thúc đầy sự hài lòng, bởi vì khi khách hàng hài lòng với sản phẩm hoặc dịch vụ, họ có xu hướng sử dụng thường xuyên hơn và trơ nên trung thành hơn. Xét về thi trường phát triển TMĐT thi TP.HCM chính là nơi tiềm năng nhất. Vi vậy, mục đích của đề tài này là đo lường tác động của các yếu tố hài lòng đến lòng trung thành của giới trẻ (18-25 tuổi) với sàn TMĐT tại TP.HCM, đồng thời giải quyết các vấn đề còn tôn đọng và đề xuất giải pháp tương ứng. Với 215 mẫu, nghiên cứu sử dụng phương pháp Phân tích hồi quy tuyến tính với SPSS 20.0 để xây dựng và kiểm tra mô hình. Có 5 yếu tố được để xuất, gồm có sự hài lòng với thiết kế website, với mức độ đa dạng của sản phẩm, với quyền riêng tư \& bảo mật, với dịch vụ giao hàng và với dịch vụ hậu mãi. Kết quả cho thấy sự hài lòng với quyền riêng tư \& bảo mật có ảnh hưởng lớn nhất đến lòng trung thành của giới trẻ, tiếp theo là sự hài lòng với dịch vụ hậu mãi và với thiết kế trang web. Ngoài ra, không có khác biệt thống kê giứa các nhóm giới tính, nghề nghiệp, tần suất truy cập sàn TMĐT, mức thu nhập hàng tháng và chi tiêu trung bình trên mỗi đơn hàng. Xét về tính ứng dụng, nghiên cứu này giúp các sàn TMĐT đưa ra chiến lược phát triển phù hợp trong việc xây dựng lòng trung thành của khách hàng trẻ và cạnh tranh hiệu quả hơn trên thị trường. Tuy nhiên, đề tài cũng có một vài han chế, cu thể như thời gian thu thập số liệu sơ cấp ngắn (một tháng), dẫn tới cỡ mẩu tương đối nhỏo. Hơn nữa, vì phương pháp thu thập là khảo sát, nghiên cứu cần được thực hiện lại cho các khu vực và quốc gia khác nhau. Ngoài ra, đề tài còn giới hạn với các sàn TMĐT trong ngành bán lẻ. Chính vì thế, nghiên cứu trong tương lai có thể cải thiện tính ứng dụng của mô hình bằng cách tăng lượng thời gian thu thập dữ liệu và khảo sát trên nhiều ngành nghề hơn. Đồng thời, phương pháp phân tích hiện đại hơn như SEM nên được áp dụng trong việc đánh giá thang đo và kiểm tra mô hình, bởi Phân tích hồi quy đa tuyến tính yêu cầu nhiều giả định và điêu này có thể dẫn tới khả năng sai sót cao khi đo lường.

Từ khoá: Sàn thương mại điện tử, Sự hài lòng, Lòng trung thành, Giới trẻ
Trích dẫn bài báo này: Nga N T Q, Vân $\mathrm{D} \mathrm{H}$. Ảnh hưởng của sự hài lòng tới lòng trung thành của giới trẻ (18-25 tuổi) với sàn thương mại điện tử tại TP.HCM. Sci. Tech. Dev. J. - Eco. Law Manag.; 4(4): 